\title{
PENGARUH EFEKTIVITAS PENGGUNAAN SISTEM PERPAJAKAN ONLINE E-TAX PADA KEPATUHAN PELAPORAN PAJAK DAERAH KABUPATEN BADUNG
}

\author{
Ni Made Estiyanti ${ }^{1}$ \\ I Putu Rawindra Wikantona ${ }^{2}$ \\ I Gede Putu Krisna Juliharta ${ }^{3}$ \\ STMIK Primakara ${ }^{1,2,3}$ \\ email: estiyanti@primakara.ac.id
}

\begin{abstract}
This study aims to analyze the effectiveness of the use of the taxation system e-tax online in compliance with the Badung Regency tax reporting. Sampling is done by method random sampling. The data collection method was carried out by distributing questionnaires to 143 taxpayers consisting of hotel, restaurant, parking and entertainment taxpayers. The analysis technique used is a simple linear regression analysis technique that is preceded by a classic assumption test and processed using the program SPSS version 16.0. The results of this study indicate an increase in the effectiveness of the use of the taxation system e-tax online will be followed by an increase in compliance with the tax reporting in the Badung Regency. And there is a significant influence on the effectiveness of the use of the taxation system e-tax online in the compliance of the Badung district tax reporting.
\end{abstract}

Keywords: $\quad$ local taxation, taxation, system effectiveness e-tax, local tax compliance.

\section{PENDAHULUAN}

Belakangan ini teknologi semakin berkembang dengan pesat. Hampir semua sektor sudah terjamah dengan kemajuan teknologi, baik itu industri ataupun pemerintahan. Pemerintah Kabupaten Badung tidak luput dari perkembangan teknologi tersebut, oleh karena itu pemerintah Kabupaten Badung telah mengembangkan suatu aplikasi berbasis web yang memudahkan masyarakat untuk melakukan pembayaran wajib pajak. Aplikasi tersebut bernama e-tax, e-tax sendiri dikembangkan beberapa tahun belakangan ini dan sudah mulai di gunakan di Kabupaten Badung dengan harapan mempermudah pekerjaan di Kabupaten Badung.

Tetapi fenomena yang terjadi saat ini justru orang-orang atau wajib pajak cenderung jarang melakukan kewajibannya dalam pelaporan pajak, hal tersebut didasari oleh berbagai faktor baik faktor internal maupun faktor eksternal. Untuk menangani masalah tersebut pemerintah telah menyiapkan Surat Pemberitahuan (SPT) untuk menanggulanginya, Sebagaimana ditentukan dalam Undang-undang Perpajakan, Surat Pemberitahuan (SPT) mempunyai fungsi sebagai suatu sarana bagi Wajib Pajak di dalam melaporkan dan mempertanggungjawabkan

penghitungan jumlah Pajak yang sebenarnya terutang. Selain itu Surat Pemberitahuan berfungsi untuk melaporkan pembayaran atau pelunasan Pajak baik yang dilakukan Wajib Pajak sendiri maupun melalui mekanisme pemotongan dan 
pemungutan yang dilakukan oleh pihak pemotong/pemungut, melaporkan harta dan kewajiban, dan pembayaran dari pemotong atau pemungut tentang pemotongan dan pemungutan Pajak yang telah dilakukan. Selain itu pemerintah juga telah mempermudah wajib pajak untuk melakukan pelaporan dengan memanfaatkan sistem pelaporan online, tetapi masalahnya sejauh manakah sistem tersebut dapat meningkatkan kemauan wajib pajak untuk melakukan pelaporan pajaknya.

\section{Rumusan Masalah}

Berdasarkan uraian latar belakang diatas, maka perumusan masalah dalam penelitian ini adalah, "Apakah pelaporan pajak daerah secara online berpengaruh pada kepatuhan wajib pajak di Kabupaten Badung?".

\section{Tujuan penelitian}

\section{Berkaitan}

dengan

permasalahan yang telah dirumuskan di atas, maka tujuan penelitian ini adalah memberikan bukti empiris bahwa pelaporan pajak online berpengaruh terhadap kepatuhan wajib pajak daerah di Kabupaten Badung.

\section{TINJAUAN PUSTAKA}

\section{Sistem E-Tax}

Sistem informasi e-tax adalah suatu sistem yang baru-baru ini dikembangkan oleh pihak Badan Pendapatan Daerah/Pasedahan Agung Kabupaten Badung (BAPENDA) yang dimana sistem ini berfungsi untuk memudahkan wajib pajak dalam melakukan pelaporan pajak.

\section{Kepatuhan Pajak}

Kepatuhan wajib pajak merupakan suatu keadaan dimana wajib pajak memenuhi semua kewajiban perpajakan dan melaksanakan hak perpajakannya (Nurmantu, 2003).

Perilaku kepatuhan seseorang merupakan interaksi antara perilaku individu, kelompok dan organisasi. Dengan demikian kepatuhan dapat didefinisikan sebagai memasukkan dan melaporkan pada waktunya informasi yang diperlukan untuk mengisi secara benar jumlah pajak terutang dan membayar pajak pada waktunya tanpa ada tindakan pemaksaan. Dalam penelitian ini, indikator kepatuhan pelaporan pajak daerah ialah sebagai berikut :

1) Pengetahuan Pajak

2) Kualitas Pelayanan

3) Pemeriksaan pajak

4) Kesadaran Wajib Pajak

5) Kepatuhan Wajib Pajak

\section{METODE PENELITIAN}

\section{a. Jenis dan Sumber Data}

Data dari penelitian ini berupa data kualitatif yang diperoleh dari responden penelitian. Sumber data dalam penelitian ini berupa kuesioner.

\section{b. Metode Penentuan Sampel}

Sampel dalam penelitian ini ialah wajib pajak daerah aktif pengguna STPPD Online di Kabupaten Badung. Teknik penentuan sampel yang digunakan ialah random sampling dimana sampel diambil secara acak.

\section{c. Responden Penelitian}

Responden penelitian diambil sebanyak 143 responden dimana responden tersebut merupakan wajib pajak yang menggunakan sistem perpajakan online e-tax sejak tahun 2015.

\section{d. Uji Instrumen Penelitian}

Data yang telah dikumpulkan kemudian diolah dan dianalisis dengan menggunakan alat bantu software SPSS. Dengan program SPSS dilakukan berbagai uji statistik, yaitu 
Journal of Applied Management and Accounting Science (JAMAS)

(Ni Made Estiyanti, I Putu Rawindra Wikantona, I Gede Putu Krisna Juliharta 10 - 17) Vol 1, No 1, Desember 2019

uji validitas, uji reabilitas, uji asumsi klasik dan analisis regresi linear sederhana.

\section{HASIL DAN PEMBAHASAN}

\section{a. Deskripsi Responden}

Kuesioner yang menjadi instrumen penelitian telah tersebar ke 143 wajib pajak daerah di Kabupaten Badung yang terdiri dari dari 95 wajib pajak hotel, 43 wajib pajak restoran, 2 wajib pajak hiburan, dan 3 wajib pajak parkir. Dari 143 kuesioner tersebar, kuesioner yang telah kembali dan dapat dijadikan data penelitian ialah sebanyak 83 kuesioner. Karakteristik responden diukur atau dianalisis dari 3 (tiga) hal, yaitu jenis kelamin, umur serta tingkat pendidikan.

b. Pembahasan

1. Uji Validitas dan Reliabilitas Terhadap Instrumen Penelitian

Tabel 1 Uji Validitas dan Reliabilitas

\begin{tabular}{|c|c|c|c|c|c|}
\hline Variabel & Item & $\begin{array}{c}\text { Korelasi } \\
\text { Produk } \\
\text { momen }\end{array}$ & $\begin{array}{c}\text { Keteran } \\
\text { gan }\end{array}$ & $\begin{array}{c}\text { Alpha } \\
\text { Cronbach }\end{array}$ & Keterangan \\
\hline \multirow{15}{*}{$\begin{array}{c}\text { Efektivitas } \\
\text { Penggunaan } \\
\text { Sistem } \\
\text { Perpajakan } \\
\text { online e-tax }\end{array}$} & $\mathrm{X} 1$ & 0,509 & Valid & \multirow{15}{*}{0,906} & \multirow{15}{*}{ Reliabel } \\
\hline & $\mathrm{X} 2$ & 0,539 & Valid & & \\
\hline & X3 & 0,845 & Valid & & \\
\hline & $\mathrm{X} 4$ & 0,856 & Valid & & \\
\hline & $\mathrm{X} 5$ & 0,517 & Valid & & \\
\hline & X6 & 0,509 & Valid & & \\
\hline & $\mathrm{X} 7$ & 0,539 & Valid & & \\
\hline & $\mathrm{X} 8$ & 0,845 & Valid & & \\
\hline & X9 & 0,856 & Valid & & \\
\hline & $\mathrm{X} 10$ & 0,517 & Valid & & \\
\hline & $\mathrm{X} 11$ & 0,509 & Valid & & \\
\hline & $\mathrm{X} 12$ & 0,539 & Valid & & \\
\hline & $\mathrm{X} 13$ & 0,845 & Valid & & \\
\hline & $\mathrm{X} 14$ & 0,856 & Valid & & \\
\hline & $\mathrm{X} 15$ & 0,517 & Valid & & \\
\hline \multirow{19}{*}{$\begin{array}{c}\text { Kepatuhan } \\
\text { pelaporan } \\
\text { pajak daerah }\end{array}$} & Y1 & 0,659 & Valid & \multirow{19}{*}{0,936} & \multirow{19}{*}{ Reliabel } \\
\hline & $\mathrm{Y} 2$ & 0,749 & Valid & & \\
\hline & Y3 & 0,713 & Valid & & \\
\hline & Y4 & 0,586 & Valid & & \\
\hline & Y5 & 0,659 & Valid & & \\
\hline & Y6 & 0,749 & Valid & & \\
\hline & Y7 & 0,713 & Valid & & \\
\hline & Y8 & 0,586 & Valid & & \\
\hline & Y9 & 0,659 & Valid & & \\
\hline & $\mathrm{Y} 10$ & 0,749 & Valid & & \\
\hline & Y11 & 0,713 & Valid & & \\
\hline & $\mathrm{Y} 12$ & 0,586 & Valid & & \\
\hline & Y13 & 0,659 & Valid & & \\
\hline & $\mathrm{Y} 14$ & 0,749 & Valid & & \\
\hline & $\mathrm{Y} 15$ & 0,713 & Valid & & \\
\hline & Y16 & 0,586 & Valid & & \\
\hline & Y17 & 0,659 & Valid & & \\
\hline & Y18 & 0,749 & Valid & & \\
\hline & Y19 & 0,713 & Valid & & \\
\hline
\end{tabular}


Journal of Applied Management and Accounting Science (JAMAS)

(Ni Made Estiyanti, I Putu Rawindra Wikantona, I Gede Putu Krisna Juliharta 10 - 17) Vol 1, No 1, Desember 2019

Suatu instrumen dalam
penelitian dikatakan valid apabila
memiliki koefesien korelasi antara
butir dengan skor total dalam
instrumen tersebut lebih besar dari
0,300 dengan tingkat kesalahan Alpha
0,05 . Suatu instrumen dikatakan
reliabel apabila memiliki koefisien
Cronbach Alpha minimal 0,600 .

2. Analisis Data Uji Normalitas

Uji normalitas bertujuan untuk melihat data yang digunakan dalam penelitian telah berdistribusi normal. Untuk mengetahui apakah residual berdistribusi normal atau tidak salah satunya dengan melakukan uji statistik non parametrik Kolmogorov-Smirnov.

\begin{tabular}{|c|c|c|}
\hline \multicolumn{3}{|c|}{ One-Sample Kolmogorov-Smirnov Test } \\
\hline & & $\begin{array}{l}\text { Unstandardiz } \\
\text { ed Residual }\end{array}$ \\
\hline $\bar{N}$ & & 83 \\
\hline Normal Parameters ${ }^{a, b}$ & Mean &, 0000000 \\
\hline & Std. Deviation & 5,10961650 \\
\hline Most Extreme & Absolute &, 115 \\
\hline Differences & Positive & ,092 \\
\hline & Negative &,- 115 \\
\hline Kolmogorov-Smirnov Z & & 1,047 \\
\hline Asymp. Sig. (2-tailed) & & ,223 \\
\hline
\end{tabular}

\section{Gambar 1 \\ Uji Normalitas}

Berdasarkan output SPSS diketahui dengan menggunakan uji diperoleh nilai Asymp. Sig. (2-tailed) 0,223 yang lebih besar dari 0,05 . Hal itu berarti residual data berdistribusi normal.

\section{Uji Heteroskedastisitas}

Cara untuk mendeteksi ada statistik Glejser. Model regresi tidak mengandung adanya heteroskedastisitas bila nilai signifikansi variabel bebasnya terhadap nilai absolute residual statistic di atas $\alpha=0,05$. tidaknya heterokedastisitas dapat

Tabel 2 Uji Heteroskedastisitas

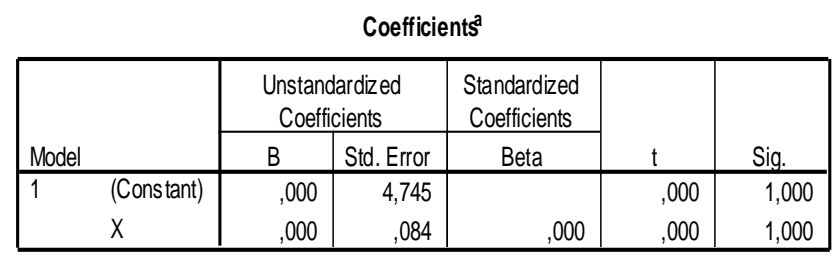

a. Dependent Variable: Abres

Hasil uji glejser diperoleh nilai signifikansi variabel efektivitas penggunaan sistem perpajakan online e-tax sebesar 1,000, nilai sig pada variabel bebas lebih besar dari 0,05. Hal ini berarti model regresi tersebut 
Journal of Applied Management and Accounting Science (JAMAS)

(Ni Made Estiyanti, I Putu Rawindra Wikantona, I Gede Putu Krisna Juliharta 10 - 17) Vol 1, No 1, Desember 2019

tidak mengandung gejala model regresi lolos dari uji asumsi heteroskedastisitas. klasik. Model yang digunakan dalam menganalisis variabel-variabel yang

Analisis Regresi Linier Sederhana

Berdasarkan pengujian asumsi klasik diatas, dapat disimpulkan bahwa mempengaruhi efektivitas penggunaan sistem perpajakan online $e$-tax adalah model analisis regresi linear sederhana dengan bantuan program SPSS.

\section{Tabel 3 Analisis Regresi Linier Sederhana}

\begin{tabular}{|c|c|c|c|c|c|c|}
\hline \multicolumn{7}{|c|}{ Coefficients } \\
\hline \multirow[b]{2}{*}{ Model } & & \multicolumn{2}{|c|}{$\begin{array}{c}\text { Unstandardized } \\
\text { Coefficients }\end{array}$} & \multirow{2}{*}{$\begin{array}{c}\begin{array}{c}\text { Standardized } \\
\text { Coefficients }\end{array} \\
\text { Beta }\end{array}$} & \multirow[b]{2}{*}{$t$} & \multirow[b]{2}{*}{ Sig. } \\
\hline & & B & Std. Error & & & \\
\hline & (Constant) & 54,645 & 4,745 & & 11,516 &, 000 \\
\hline & $x$ &, 324 & ,084 &, 395 & 3,870 &, 000 \\
\hline
\end{tabular}

a. Dependent Variable: $Y$

Dari hasil analisis regresi pada Tabel $4.4 \mathrm{di}$ atas dapat disusun persamaan regresi sebagai berikut: $\mathrm{Y}=54,645+0,324 \mathrm{X} 1$

Berdasarkan nilai a, b1 diperoleh persamaan garis regresi linear sederhana antara efektivitas penggunaan sistem perpajakan online e-tax terhadap kepatuhan pelaporan pajak daerah Kabupaten Badung memberikan informasi bahwa:

1. Konstanta $=54,645$ artinya apabila tidak ada perhatian terhadap efektivitas penggunaan sistem perpajakan online e-tax maka skor kepatuhan pelaporan pajak daerah kabupaten Badung rata-rata sebesar 54,645.
2. Koefisien regresi efektivitas penggunaan sistem perpajakan online e-tax bernilai positif $\mathrm{b} 1=$ 0,324 artinya meningkatnya efektivitas penggunaan sistem perpajakan online tax akan diikuti oleh meningkatnya kepatuhan pelaporan pajak daerah Kabupaten Badung.

\section{Analisis Determinasi}

Analisis ini digunakan untuk mengetahui persentase besarnya pengaruh variabel yang diteliti, yaitu antara variabel terhadap variabel terikat (Y).

\section{Tabel 4 Analisis Determinasi}

Model Summary
\begin{tabular}{|l|r|r|r|r|}
\hline Model & $\mathrm{R}$ & R Square & $\begin{array}{l}\text { Adjusted } \\
\text { R Square }\end{array}$ & $\begin{array}{r}\text { Std. Error of } \\
\text { the Estimate }\end{array}$ \\
\hline 1 &, $395^{\mathrm{a}}$ &, 156 &, 146 & 5,14106 \\
\hline
\end{tabular}
a. Predictors: (Constant), $\mathrm{X}$
b. Dependent Variable: $Y$




\section{T-test}

Berdasarkan hasil analisis regresi pada tabel 4.5 , nilai koefesien determinasi sebesar 0,156 atau $15,6 \%$ memiliki arti bahwa $15,6 \%$ variasi variabel nilai efektivitas penggunaan sistem perpajakan onlie e-tax, dimana efektivitas penggunaan sistem perpajakan merupakan salah satu dari 5 (lima) faktor yaitu faktor kualitas pelayanan yang mempengaruhi kepatuhan pelaporan pajak daerah Kabupaten Badung. Sisanya sebesar $84,4 \%$ dipengaruhi oleh faktor lain yang tidak diteliti pada kesempatan ini yakni faktor pengetahuan pajak, pemeriksaan pajak, kesadaran wajib pajak, dan kepatuhan wajib pajak. Uji $\mathrm{t}$ pada dasarnya menunjukkan pengaruh variabel bebas terhadap variabel terikat. Pada uji ini dapat dilakukan dengan membandingkan tingkat signifikansinya. Jika nilai signifikan lebih kecil dari alpha 0,05 menunjukkan bahwa $H_{0}$ ditolak dan $H_{a}$ diterima. Sehingga perlu menguji signifikasi masing-masing koefisien regresi, yaitu untuk :

$>$ Untuk mengetahui apakah efektivitas penggunaan sistem perpajakan online e-tax berpengaruh terhadap kepatuhan pelaporan pajak daerah kabupaten adalah memang nyata terjadi (signifikan) atau hanya diperoleh oleh secara kebetulan.

Langkah-langkah uji statistiknya adalah :

a. Membuat Formulasi Hipotesis

- $\mathrm{H}_{0}: \mathrm{b}_{1} \neq 0$,

berarti efektivitas penggunaan sistem peperjakan online e-tax tidak berpengaruh terhadap kepatuhan pelaporan pajak daerah Kabupaten Badung

- $\mathrm{H}_{1}: \mathrm{b}_{1}>0$, berarti; efektivitas penggunaan sistem perpajakan online e-tax pada kepatuhan pelaporan pajak daerah Kabupaten Badung.

b. Menghitung $t_{\text {hitung }}$

Diketahui:

$\mathrm{t}_{\text {hitung }}=3,870, \operatorname{sig} 0,000$

\begin{tabular}{|c|c|c|c|c|c|c|}
\hline \multicolumn{7}{|c|}{ Coefficients $^{\mathrm{a}}$} \\
\hline \multirow[b]{2}{*}{ Model } & & \multicolumn{2}{|c|}{$\begin{array}{c}\text { Unstandardized } \\
\text { Coefficients }\end{array}$} & \multirow{2}{*}{$\begin{array}{c}\text { Standardized } \\
\text { Coefficients }\end{array}$} & \multirow[b]{2}{*}{$t$} & \multirow[b]{2}{*}{ Sig. } \\
\hline & & $B$ & Std. Error & & & \\
\hline 1 & (Constant) & 54,645 & 4,745 & & 11,516 &, 000 \\
\hline & $x$ & ,324 & ,084 & ,395 & 3,870 & ,000 \\
\hline
\end{tabular}

c. Kriteria Pengujian

1) Jika sig $>0,05$ maka Ho diterima

2) Jika $\operatorname{sig} \leq 0,05$ maka Ho ditolak

d. Keputusan

Nilai $t_{\text {hitung }}=3,870 \operatorname{sig} 0,000$ berarti $\mathrm{H}_{1}$ diterima. Dengan kata lain ada pengaruh yang signifikan efektivitas penggunaan sistem perpajakan online e-tax pada kepatuhan pelaporan pajak daerah kabupaten Badung

\section{SIMPULAN DAN SARAN}

Simpulan

Berdasarkan hasil pengujian dengan analisis regresi linier sederhana, maka penelitian ini membuktikan bahwa efektivitas penggunaan sistem perpajakan online e-tax berpengaruh positif dan signifikan terhadap kepatuhan pelaporan pajak daerah Kabupaten Badung. 


\section{Saran}

Maka bahwa diharapkan pihak

Bappeda Kabupaten Badung lebih memperhatikan sistem secara intens seperti update dan maintenance secara berkala agar sistem lebih mudah digunakan dan diakses oleh wajib pajak di kemudian hari. Penelitian ini hanya menguji variabel efektivitas penggunaan sistem perpajakan online e-tax terhadap variabel kepatuhan pelaporan wajib pajak daerah, maka untuk penelitian selanjutnya, diharapkan untuk memperluas cakupan penelitiannya. Utamanya dari segi jenis variabel maupun dari segi cakupan wilayah, dan jumlah atau jenis respondennya. Karena sistem informasi pelaporan pajak online e-tax masih akan dikembangkan lagi maka diharapkan penelitian selanjutnya bisa lebih berkembang dan bisa lebih akurat hasil penelitiannya untuk bisa mendukung penelitian sebelumnya.

\section{DAFTAR PUSTAKA}

Kementerian Keuangan Direktorat Jendral Pajak(2019). Wajib Pajak dan NPWP[online]. Available:www.pajak.go.id/id /wajib-pajak-dan-npwp

Yanuar, Toma, Putra Endang dan Siti Astuti Riyadi. 2015. Pengaruh Penerapan Sistem Administrasi E-Registration, E-Spt, Dan E-Filing Terhadap Tingkat Kepatuhan Wajib Pajak. Jurnal Administrasi Bisnis - Perpajakan (JEJAK) Vol. 6 No. 1

Rahayu, Sri dan Ita Salsalina Lingga. 2009. Pengaruh Modernisasi Sistem Administrasi Perpajakan terhadap
Kepatuhan Wajib Pajak. Jurnal

Akuntansi Vol.1 hal. 119-138

Undang-Undang Republik Indonesia

Nomor 28 Tahun 2007

Perubahan Ketiga Atas

Undang-Undang Nomor 6

Tahun $1983 \quad$ Tentang

Ketentuan Umum Dan Tata

Cara Perpajakan

Prof. Dr. MHJ Smeeth. De Economische Betekenis der Belastinger. 1951.

I Cenik Ardana, Lukman dan Hendro. Sistem Informasi Akuntansi. Jakarta:Mitra. Wacana Media. 2016.

Safri Nurmantu. Pengantar Perpajakan edisi ke 2. Jakarta: Yayasan Obor Indonesia. 2003.

Undang-Undang Nomor 36 Tahun 2008 tentang Pajak Penghasilan

Peraturan Menteri Keuangan No.192/PMK.03/2007 tentang Tata Cara Penetapan Wajib Pajak Dengan Kriteria Tertentu Dalam Rangka Pengembalian Pendahuluan Kelebihan Pembayaran Pajak

Mardiasomo, 2016. Perpajakan. Yogyakarta: C.V Andi Offset

R. Santoso Brotodiharjo. Pengantar Ilmu Hukum Pajak. Bandung: Refika Aditama. 2003.

Peraturan Pemerintah Nomer 24 Tahun 2005 tentang Standar Akuntasi Pemerintahan 
Journal of Applied Management and Accounting Science (JAMAS)

(Ni Made Estiyanti, I Putu Rawindra Wikantona, I Gede Putu Krisna Juliharta 10 - 17) Vol 1, No 1, Desember 2019

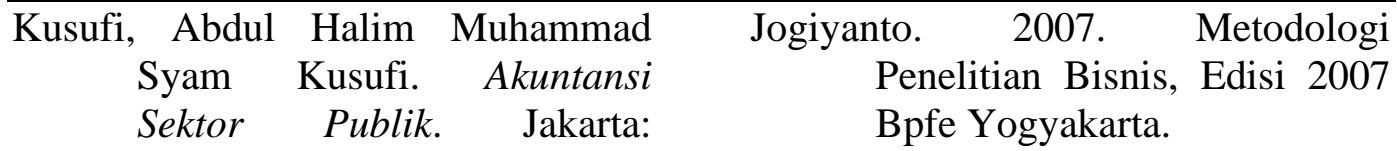

Selemba Empat. 2014.

Nordiawan Deddi. Akuntansi Sektor

Publik. Jakarta: Salemba Empat. 2006.

Muhammad Gade. Akuntansi

Pemerintahan. Jakarta:

Lembaga Penerbit Fakultas

Ekonomi Universitas

Indonesia. 2000.

Imam Ghozali. 2011. Aplikasi Analisis Multivariate dengan Program SPSS. Semarang: Badan Penerbit Universitas Diponegoro.

Peraturan Daerah Kabupaten Tabanan

Nomor 24 Tahun 2011

Tentang Pajak Hotel

Peraturan Daerah Kabupaten Badung Nomor 2 Tahun 2016 tentang Sistem Online Pajak Daerah

Undang-undang Nomor 28 Tahun 2009 Tentang Pajak Daerah dan Retribusi Daerah

Uma Sekaran ,Roger Bougie. Research and Method for Business A Skill Building Approach (5 ${ }^{\text {th }}$ Edition). United Kingdom: John Wiley \& Sons Ltd. 2010.

Sugiyono. Metode Penelitian Kuantitatif, Kualitatif dan $R \& D$. Bandung: PT. Alfabet. 2016. 